narrowest, while the lateral ones are abbreviated behind. The front of the head is brown, while the jaws and other mouth parts are nearly black.

Like all insects, these beetles, both as larvæ and imago, are very susceptible to gasoline or bi-sulphide of carbon. Both of these, used in large quantities, were quickly fatal to the insects. Like the carpet beetle, they infest upholstered furniture between the folds, especially where the back joins the seat. It is easy to drench such parts of a sofa or chair with gasoline and destroy the larvæ of either moth or beetle.

Nearly every year brings examples of such change of habits as described above. Such incursions, present and prospective, emphasize the importance of thoroughly-trained entomologists in every state of our country.

THE NOCTUIDA OF EUROPE AND NORTH AMERICA.

$$
\text { (Third Paper.) }
$$

BY A R. GROTE, A. M., BREMEN, Germany.

Tribe Agrotini.

The tibiæ are usually all spinose, the eyes naked, the body untufted, the form normal, the male antennæ of various structure, pectinated, brushlike, simple. The European species are referred by Lederer all to one genus, Agrotis of Hübner. Nevertheless, I think the yellow-winged forms may well be separated under Hiria and Tryphana. Of these yellow-winged forms, with flattened abdomen, we have only one $T$. Chardinyi, from Anticosti and Maine, considered identical with the Siberian species of the same name, described originally by Boisduval under Anarta. For the structure of Agrotis, I refer the student to a paper of unine on the genus, CAN. ENT., XV., $5 \mathrm{I}$. This genus seems of general distribution, although, perhaps, most numerously represented by species in North America. To this tribe, I would refer certain American genera, with few species, which seem peculiar. These are: Carneades, which differs by a frontal tubercle; Richia, which resembles Ammoconia in liaving a thoracic rigid tuft, but has simple antennæ; Adita, with a claw on front tibiæ; Agrotiphila, with narrowed eyes ; Anytus, with lashes; the peculiar genus Ufeus, and, finally, Copablepharon, which has some 
resemblances to the Heliothians, and superficially recalls Arsilonche. The position of some of these genera is debatable, and the immature stages almost entirely unknown. We may briefly compare the European and American representatives of Agrotis. In Europe, about izo species are known; we have a preliminary list of over 200 . Divisions of the genus into groups have been proposed on peculiarities of the genitalia, which seem convenient, but are probably of less importance than the armature; hence, I would prefer to divide the genus, primarily, into two groups, the species with unarmed fore-tibiæ, and those with all the tibiæ armed. When all the species are compared, there will probably be found peculiarities in the armature of the front tibiæ to warrant further divisions. The relationship of the American species to the European is evidenced by the identical forms, i. e., baja, ypsilon, plecta, sancia, etc., then by the representative forms, i. e. haruspica, phyllophora, etc. The species from the west coast have largely a European facies; the Labrador species are found, with other Arctic forms, on the summit of Mount Washington. We may regard this genus as of very general, pre-glacial distribution ; but evidently a greater number of species feed, in the larval condition, upon plants now found in temperate latitudes. Setting the question of the allied genera with mostly few species aside, the affinity of the two faunæ is quite evident. It is a little singular that the yellow-winged forms are so feebly represented in North America. Their presence gives a somewhat peculiar aspect to the European fauna. The occurrence of yellowwinged species is not unusual in the Noctuidce. We find them in Oncochemis, Hadena and Anarta among usually fuscous species.

\section{Tribe Madenini.}

Leaving the Dicopid genera, which seem peculiar, we now come to a group of typical Owlet moths, which differ from the Agrotini mainly in their usually unarmed tibix and tufted, rougher, body covering. In the first genera, the eyes are hairy; in Fishia, the tibia are spinose; in Copimamestra, the front tibia have a claw. This latter genus is founded for the European brassice and its American representative occidenta. Mamestra is a typical Hadenoid genus with hairy eyes, and Dianthocia merely differs by the external ovipositor. These two genera, or generic groups in our fauna, show a similar relation to the European fauna as with Agrotis. Whether our trifolii (albifusa) is identical with the European, may not be certain, but the genus has several representative species 
such as nimbosa, atlantica, subjuncta, etc. In Dianthocia, we have $D$. bella, which represents the European D. Magnolii. America has the ustual preponderance of species, over seventy, while Europe has fiftyeight of the two together. In my lists I have not separated the forms of Dianthacia, partly because the character was not easy to verify, or I had only males, while the pupa, which r,resents some peculiarities as studied in Europe, is quite unknown. Peculiar American Hadenoid genera, with hairy eyes, seem to be Nephelodes, Admetovis, Tricholita, Trichoclea, Trichopolia and Eupsephopcectes.

I would here draw attention to the fact, that the generic characters in the Noctuidee and the moths generally are of such a nature that a difference of opinion may legitimately arise. Undoubtedly, an ultimate and better opinion may be obtained, but criticism is to be only indulged ir. with that moderation which the nature of the subject demands. Far different is it with matters concerning positive or actual structure, where the empiric has before him a certain specimen under the microscope. In such cases, as with the genus Cerathosia, where the describer erroneousiy describes the neuration or other actual features, a positive error is committed and the author earns that measure of opprobrium which belongs to defective work in Natural History.

The European Hadenoid genera, with naked and lashed eyes, Episema. Thecophora and Dichonia seem to be absent from our fauna. Polia, which has the antennæ tufted at base and usually pectinate or serrated in the males, has eleven European species; in the Bull. U. S. Geol. Surv, VI., 266, I have given the list of ten American forms referred here, whether they are all strictly correct, I am uncertain. The European genera, with few species, Metopoceras, Cladocera, Heliophobus, Ulochlcena, Oxytrypia, are yet without described American species. Gueneè's Chariptera festa seems to be the Cerma cora of Hübner, and not to be congeneric with the European viridana. Mr. Morrison's Valeria Grotei has a claw on the fore tibia; consequently is not congeneric with the European jaspidea, but seems to be allied to Dicopis.

The genus Oncocnemis is a smooth, almost Agrotid form, considered by Herrich-Schaeffer as allied to Heliothis with a claw on the front tibix, represented by two Russian species, of which confusa has a representative form in the Californian Behrensi. I have described the large number of nineteen American species (three having yellow secondaries, Hayesi, 
Dayi and mirificalis), while other authors have added four; our most beautiful Eastern form being the atrifasciata of Mr. Morrison, which I refer to this genus, it being related apparently to the grey forms, such as Chandleri, riparia, etc., the median space filled with black. I refer two Western species to the European genus Valeria, opina and conserta, and one Eastern species, stigmata, to the European genus Dryobota. Peculiar American Hadenoid genera, with naked eyes, seem to be Arthrochlora, Hillia, Homohadena, Pachypolia and Hadenella. The typical genus, Hadena itself,seems to have a parallel representation in North America with the other leading genera Apatela, Agrotis and Mamestra, from which latter genus the species differ in having naked eyes. It offers both identical and representative species with the European forms, and again an excess in number, over sixty to over forty. The related genus Hyppa with its one European species has a representative American form xylinoides. I have identified the European Dipterygia pinastri as occurring in North America ; whether this is a survival, or a more recent importation, is doubtful, perhaps the latter. Of the European genus Actinotia, we have two species; of Callopistria, one. A strong analogy of the two faunæ is offered by the genera clustering about Euplexia, the single species of which latter, lucipara, is found from the East to California, and is apparently an unchanged survival and identical with the European; I have found the larve ou a number of plants, among them the common Fuchsia. These genera are Trigonophora, and Brotolomia, each with representative American forms, while the European genus Habryntis is perhaps not found in America, nor, conversely, the American genus Conservula in Europe. Prodenia, which has one European, has at least four North American species. This genus is a Southern form, intruding into the European fauna from the Mediterranean and Asia Minor; in America, more plentiful in the Southern States, where an ailied form, the Laphygma frugiperda of Abbot and Smith, is destructive to corn. We have nothing like the wide-winged European Mania maura, so far as my knowledge goes. The determination of what species is the real type of the earlier genera of Ochsenheimer and other authors is a matter of some difficulty, owing to the fact that the species were loosely associated, and the characters we today consider of importance neglected. Not a single species included by Boisduval in 1829 under Luperina is placed under Luperina by Lederer. The true type of Luperina may, I think, be considered to be the Euro- 
pean testacea, which Lederer includes under Apamea Tr. Probably the true type of Apamea may be found in nictitans, one of the original species.

Of neither Luperina Boisd. (== Apamea Led.), or Ledereria $m$. (=Luperina Led. non Boisd.), do I know American species. Apamea nictitans occurs with us however, from California to the East probably as an unchanged survival, not only in the typical, but also in the varietal European forms. Whether nictitans and certain allied species are distinct from Gortyna, I, however, doubt, and it is probable that we have but one genus which European authors call Hydrocia Guen. Now the type of Hydracia is micacea, as cited in the Species Gèneral. But the type of Gortyna is already designated by Hübner as micaced, consequently Hyaracia must fall. For Gortyna Led, with its one species flavago, which differs from Hydracia by its mucronate clypeus, the term Ochria must be used, as I have pointed out. The objectors to Hübner must be told that Ochsenheimer cites him as authority, himself giving no diagnoses to the Noctuid genera; that the older Noctuid generic names are all incompletely founded, that there is no standard for exact generic definition, and finally, that Hübner has given us more information and a better classification for the Noctuidce than any author before his time. Hübner separates the Thyatirince correctly for the first time; he is the author of the leading generic divisions and names, Apatela, Agrotis, Heliothis, etc., names which have been wrongly credited to his successors. The North American species of Gortyna (including those separated by me with nictitans) are much more numerous than the European. The finest species is our beautiful Gortyna speciosissima. We have two species with mucronate clypeus; one from the East, buffaloensis, and another from the West. In omamentation these species resemble the other Gortynce, but we must refer them to Ochria, together with the European flavago. Our North American species which most nearly resembles the European flavago, is, however, my Cataphracta, but here the front is smooth. The question then arises as to the value of the frontal tubercle; whether it may not be developed as easily as modifications in the color or pattern of ornamentation. Such questions are beyond our present ability to answer. We must use what characters we find upon which to found our genera, but the difficulties which the subject presents should preclude all notion that our present opinions are infallible, or that we have any reasonable pretext to arrogate to ourselves a superiority in our classi- 
fication which allows us to speak unduly and depreciatingly of those who studied these matters long ago.

As with former groups, the North American Hadenini show a prevailing affinity with the European fauna. The amount of divergence can hardly be shown until all the species are carefully compared, but we can be sure it will not outweigh the resemblance. PRELIMINARY CATALOGUE OF THE ARCTIIDE OF TEM
PERATE NORTH AMERICA, WITH NOTES.

BY JOHN B. SMITH, NEW BRUNSWICK, N. J.

(Continued from page 775 .)

Sub-Family ARCTIINE.

In the previous paper I explained the sense in which this term is used, and nothing further in the way of definition need be said on that head.

\section{Genus Crocota Hbn.}

I816-Verzeichniss; Samml., Eur. Schm., III., 254.

This genus is in a sad state. It is almost impossible to identify species satisfactorily, and yet new species are constantly described. The matter has been further confused by Mr. Grote's persistent refusal to refer to Mr. Reakirt's species, for without referring them positively as synonyms to any species, he says he cannot believe that they refer to species different from those recognized by him, and therefore he ignores them altogether. This has had the effect of causing others to lose track of the descriptions which, poor as they may be, yet are necessary to be referred to. We know nothing at all as yet as to the range of variation in the genus, and species are based upon the most indefinite comparative features of colour and appearance.

Using $C$. ferruginosa as subject: The head is free, rather small ; eyes large, somewhat prominent; ocelli distinct; vestiture scaly, smooth; antennæ of male with the joints marked, scarcely serrate, with fine lateral ciliæ, palpi moderate in length, straight or slightly drooping. Thoracic vestiture scaly. Iegs closely scaled, posterior longest, the spurs normal $-i$. e., middle with one, posterior with two pairs. The tongue is rather short, but corneous and spiral. Wings proportionately wide and short, 